\title{
Contributing Factors Of Teenage Pregnancy Among Pregnant Teenagers At Selected Hospitals Of Dhaulagiri Zone, Nepal
}

\author{
S Chalise ${ }^{1}, \mathrm{~S}$ Bajracharya ${ }^{2}$ \\ ${ }^{I}$ (Norvic Institute of Nursing Education, Maharajgunj, Kathmandu, Nepal) \\ ${ }^{2}$ (College of Nursing, Chitwan Medical College, Bharatpur -13 Chitwan, Nepal)
}

\begin{abstract}
Teenage pregnancy is a challenging issue and public health concern. A descriptive study was conducted to find out contributing factors of teenage pregnancy among the pregnant teenagers at selected hospitals. Fifty pregnant teenagers attending these hospitals for antenatal check-up and delivery were selected by using non- probability purposive sampling. Data were collected by semi structured interview schedule and analyzed and interpreted using descriptive statistics. The finding of this study revealed that $48 \%$ respondents were 18 years old, $98 \%$ were Hindu, $78 \%$ were homemaker, and $15 \%$ had positive history of teenage pregnancy in family either side. Regarding contributing factors of teenage pregnancy, $76 \%$ had lower secondary level of education, $92 \%$ were living in rural areas, $34 \%$ and $58 \%$ respectively had no knowledge about its consequences and disadvantage, $14 \%$ had faced problem in getting contraceptive of own choice, 94\% had cultural acceptance for early marriage and in 58\% guardians were less strict in trying to monitor activity. For minimizing the teenage pregnancy, chances for girls in formal education should be increased, vocational training should be provided to those not continuing their education, and parents need to be equipped with knowledge regarding teenage pregnancy.
\end{abstract}

Keywords: Contributing factors, Teenage, Pregnancy

\section{Introduction}

Adolescent are as individuals within the age group of 10-19 years. During this time most adolescents start exploring of sexuality and some young couples may start sexual relationships. ${ }^{[1]}$ Teenage pregnancy continues to be a challenging issue and public health concern for families, health workers, societies, governments and adolescents themselves both in developed and developing countries. ${ }^{[2]}$

Globally about 16 million girls aged 15 to 19 years and 2 million girls under the age of 15 give birth every year. Evidence further indicates that nearly $60 \%$ of all girls are married by the age of 18 years and one fourth is married by the age of 15 years in South Asia, whereas within South Asia, the recorded teenage pregnancy rate is highest in Bangladesh $(35 \%)$ followed by Nepal $(21 \%)$ and India $(21 \%) .{ }^{[3]}$ Teenage pregnancy begins early in Nepal, with almost 23 percent of Nepalese women have giving birth before reaching age 18, while about 48 percent have given birth by age $20 .{ }^{[4]}$

In order to overcome this problem in Nepal, a clear understanding of educational level, socio economical status, custom and tradition of early marriage, knowledge about contraceptive, decision-making authority of respondent, family background and informal education about teenage pregnancy is required.

\section{Research Methods And Materials}

Cross sectional, descriptive research design was adopted to identify the contributing factors of teenage pregnancy among the pregnant teenagers in selected hospital of Dhaulagiri Zone. The population of the study was all pregnant teenagers attending Antenatal check-up outpatient department and labor room in Dhaulagiri Zone Hospital and Myagdi district hospital of Dhaulagiri Zone. Non-probability purposive sampling technique was adopted to select the required sample.

Study was conducted after the approval of research committee. Formal permission was taken from the Chitwan Medical College, College of Nursing, Bharatpur, Dhaulagiri Zone Hospital and Myagdi district hospital. Informed consent from each participant was taken for the interview and objective of the study was explained to the respondents. Data collection was done by interview method using semi-structured questionnaire. SPSS for windows was used for the analysis of data.

\section{Results}

Table (1) Socio-demographic characteristics of respondents $(\mathrm{n}=50)$

\begin{tabular}{|l|l|l|}
\hline Variables & Frequency & Percent \\
\hline Age in years & & \\
\hline 16 & 10 & 20 \\
\hline 17 & 16 & 32 \\
\hline 18 & 24 & 48 \\
\hline
\end{tabular}




\begin{tabular}{|c|c|c|}
\hline Ethnicity & & \\
\hline Dalit & 7 & 14 \\
\hline Disadvantage Janjati & 22 & 44 \\
\hline Relatively Disadvantage Janjati & 1 & 2 \\
\hline Ungroup Cast & 20 & 40 \\
\hline \multicolumn{3}{|l|}{ Religion } \\
\hline Hindu & 49 & 98 \\
\hline Buddhist & 1 & 2 \\
\hline \multicolumn{3}{|l|}{ Occupation } \\
\hline Student & 5 & 10 \\
\hline Agriculture & 7 & 14 \\
\hline Housewife & 38 & 76 \\
\hline \multicolumn{3}{|l|}{ Place of origin } \\
\hline Rural & 46 & 92 \\
\hline Urban & 4 & 8 \\
\hline \multicolumn{3}{|l|}{ Type of family } \\
\hline Nuclear & 37 & 74 \\
\hline Joint & 13 & 26 \\
\hline
\end{tabular}

Table 1 shows that 24 (48\%) respondents were in the age of 18 years, 22 (44\%) from disadvantage Janjati, 20 (40\%) from ungrouped caste, 49 (98\%) were Hindu. Regarding occupation, 38 (76\%) were housewife, 46 (92\%) were from rural area, 37 (74\%) were grown up in nuclear family.

Table (2) Family history of teenage pregnancy and relation with the person

\begin{tabular}{|l|l|l|}
\hline Variables & Frequency & Percent \\
\hline History of teenage pregnancy in family- either side (n=50) & & \\
\hline Yes & 15 & 30 \\
\hline No & 35 & 70 \\
\hline Relation with person (n=15) & & \\
\hline Elder sister & 8 & 53.3 \\
\hline Sister in law (maternal house) & 2 & 13 \\
\hline Sister in law (own house) & 4 & 26 \\
\hline Cousin sister & 1 & 6 \\
\hline
\end{tabular}

Table 2 shows that 15 (30\%) of the respondents had positive history of teenage pregnancy in family either side, among them in 8 (53.3\%) of the cases were in elder sister.

Table (3) Respondent's educational level and economic status $(\mathrm{n}=50)$

\begin{tabular}{|l|l|l|}
\hline Variables & Frequency & Percent \\
\hline Educational level & & \\
\hline Secondary level & 38 & 76 \\
\hline Higher secondary level & 12 & 24 \\
\hline Economic status & & \\
\hline Not sufficient to eat for 1 year & 18 & 36 \\
\hline Sufficient to eat for 1 year & 27 & 54 \\
\hline Extra saving & 5 & 10 \\
\hline
\end{tabular}

Table 3 indicates that maximum number of respondents $38(76 \%)$ had secondary level of education and 27 $(54 \%)$ respondent's earning was sufficient to eat for 1 year.

Table (4) Reasons behind early marriage and teenage pregnancy ( $\mathrm{n}=50)$

\begin{tabular}{|l|l|l|}
\hline Variables & Frequency & Percent \\
\hline $\begin{array}{l}\text { Reasons of early marriage** } \\
\text { Low socioeconomic status of parents }\end{array}$ & 4 & 8 \\
\hline Poor academic condition & 9 & 18 \\
\hline Forced by parents & 2 & 4 \\
\hline Voluntarily & 49 & 98 \\
\hline Peer group influence & 1 & 2 \\
\hline Reasons of teenage pregnancy** & & \\
\hline Desire for the baby by in laws & 40 & 80 \\
\hline Desire for baby by own parents & 8 & 16 \\
\hline Desire for baby by husband & 48 & 96 \\
\hline Own desire for baby & 37 & 74 \\
\hline
\end{tabular}

**Multiple responses 
Table 4 shows that $49(98 \%)$ of the respondents married early voluntarily. In $48(96 \%)$ respondents, reasons of teenage pregnancy was desire for baby by husband, in $40(80 \%)$ desire for the baby by in laws, and in 37 (74\%) own desire for baby was the reason.

Table (5) Knowledge on consequences of teenage pregnancy for both mother and baby $(\mathrm{n}=50)$

\begin{tabular}{|l|l|l|}
\hline Variables & Frequency & Percent \\
\hline $\begin{array}{l}\text { Knowledge on Consequences } \\
\text { Present }\end{array}$ & 17 & 34 \\
\hline Absent & 33 & 66 \\
\hline $\begin{array}{l}\text { If yes consequences are **(n=17) } \\
\text { Anemia in mothers* }\end{array}$ & 13 & 76.47 \\
\hline Congenital abnormality in baby* & 16 & 94.11 \\
\hline Diabetes Mellitus in mother & 4 & 23 \\
\hline Pregnancy induced HTN in mother* & 11 & 64.7 \\
\hline Low Birth Weight in baby* & 15 & 88.23 \\
\hline Uterine prolapse in mother* & 11 & 64.7 \\
\hline
\end{tabular}

\section{**multiple responses}

*correct response

Table 5 shows that 17 (34\%) respondents had some knowledge about consequences and $33(66 \%)$ had no knowledge. Among those who had some knowledge, $16(94.11 \%)$ had knowledge on congenital abnormality in baby, 15 (88\%) had knowledge on low birth weight in baby, 13 (76.6 \%) had knowledge on anemia in mother and $11(64 \%)$ respondents had knowledge on pregnancy-induced hypertension and uterine prolapsed in mother.

Table (6) Knowledge about disadvantage of teenage pregnancy

\begin{tabular}{|l|l|l|}
\hline Variables & Frequency & Percent \\
\hline Disadvantage $(\mathrm{n}=50)$ & & \\
\hline Yes & 21 & 42 \\
\hline No & 29 & 58 \\
\hline If yes disadvantages are** $(\mathrm{n}=21)$ & & \\
\hline Increased self esteem & 4 & 19 \\
\hline Sudden increase in responsibility* & 13 & 61.9 \\
\hline Discontinuation of education* & 19 & 90.5 \\
\hline Financial and emotional problem* & 20 & 95.2 \\
\hline Can cause other disease* & 14 & 66.7 \\
\hline Sexually transmitted infection* & 13 & 61.9 \\
\hline
\end{tabular}

\section{**multiple responses}

*Correct response

Table 6 shows that $21(42 \%)$ respondents had some knowledge about disadvantages of teenage pregnancy and $29(58 \%)$ had no knowledge. Knowledge was present about financial and emotional problem in $20(95.2 \%)$, discontinuation of education in $19(90.5 \%)$, causes of other diseases in $14(66.7 \%)$ and sudden increase in responsibility and sexually transmitted infection in $13(61.9 \%)$.

Table (7) Formal informal education about teenage pregnancy

\begin{tabular}{|l|l|l|}
\hline Variables & Frequency & Percent \\
\hline Formal Education $(\mathrm{n}=50)$ & & \\
\hline Taken & 18 & 36 \\
\hline Not taken & 32 & 64 \\
\hline Informal Education $(\mathrm{n}=50)$ & & \\
\hline Yes & 30 & 60 \\
\hline No & 20 & 40 \\
\hline $\begin{array}{l}\text { If yes, Sources of Information**(n=30) } \\
\text { Own parents }\end{array}$ & 14 & \\
\hline Teachers & 18 & 46.7 \\
\hline Peer groups & 24 & 60 \\
\hline Books & 16 & 80 \\
\hline Mass media & 23 & 53.3 \\
\hline In-laws & 2 & 76.7 \\
\hline Siblings & 18 & 6.7 \\
\hline
\end{tabular}

\section{**multiple responses}

Table 7 shows 18 (36\%) respondents had taken some formal education about teenage pregnancy, and $30(60 \%)$ respondents had informal education. The source of information was peer groups in $24(80 \%)$, mass 
media in $23(76 \%)$, teachers and siblings in $18(60 \%)$, books in $16(53 \%)$, own parents in $14(46.6 \%)$ and inlaws in $2(6.7 \%)$ respondents.

Table (8) Use of family planning method and problem faced in getting contraceptive

\begin{tabular}{|l|l|l|}
\hline Variables & Frequency & Percent \\
\hline $\begin{array}{l}\text { Use of Family Planning Method }(\mathrm{n}=50) \\
\text { Used }\end{array}$ & 10 & 20 \\
\hline Not used & 40 & 80 \\
\hline $\begin{array}{l}\text { Methods of Family Planning used }(\mathrm{n}=10) \\
\text { Condom by husband }\end{array}$ & 9 & 90 \\
\hline Oral combined pills & 1 & 10 \\
\hline $\begin{array}{l}\text { Problem Faced in Getting Contraceptive }(\mathrm{n}=50) \\
\text { Yes }\end{array}$ & 7 & 14 \\
\hline No & 43 & 86 \\
\hline $\begin{array}{l}\text { If yes types of Problems }(\mathrm{n}=7)^{* *} \\
\text { Avoidance by in-laws }\end{array}$ & 7 & 100 \\
\hline Avoidance by husband & 7 & 100 \\
\hline
\end{tabular}

\section{**multiple responses}

Table 8 shows that only $10(20 \%)$ respondents had used methods of family planning, among them in 9 $(90 \%)$ respondents the method was condom by husband and in 1(10\%) oral combined pills. Seven respondents (14\%) faced problem getting the contraceptives.

Table (9) Cultural acceptance for early marriage and decision-making authority for pregnancy $(\mathrm{n}=50)$

\begin{tabular}{|l|l|l|}
\hline Variables & Frequency & Percent \\
\hline $\begin{array}{l}\text { Cultural Acceptance } \\
\text { Yes }\end{array}$ & 47 & 94 \\
\hline No & 3 & 6 \\
\hline $\begin{array}{l}\text { Decision Making Authority } \\
\text { Family }\end{array}$ & 7 & 14 \\
\hline Husband and wife & 43 & 86 \\
\hline
\end{tabular}

Table 9 shows that early marriage was culturally accepted in 47 (94\%) respondents and decision-making authority for pregnancy remained upon both husband and wife in $43(86 \%)$ respondents.

\section{Discussion}

The prime contributing factors of teenage pregnancy according to this study were limited opportunity for education and job, lack of awareness program about teenage pregnancy, lack of knowledge about disadvantage and consequences of teenage pregnancy, unavailability of formal education about teenage pregnancy, cultural acceptance for early marriage, living in rural areas and less strictness by guardians in trying to monitor activities.

In this study, 94\% of the respondents said cultural acceptance for early marriage was contributing factor of teenage pregnancy, which was similar to the finding of Acharya et.al. that revealed early age at marriage is culturally acceptable in south Asian culture. ${ }^{[5]}$

Similarly, $92 \%$ of the respondents said that living in rural areas was contributing factor of teenage pregnancy. This finding is similar to the study done by Nepal Demography and Health survey, which revealed that teenage pregnancy, is double the number in rural areas compared to urban area. ${ }^{[4]}$

About $76 \%$ of the respondents, who were homemaker; felt their occupation was main contributing factor of teenage pregnancy and $64 \%$ of the respondents had no formal education about teenage pregnancy. This result was similar to the study conducted by Muchuruza, which showed that the risk was fifteen times higher in respondents with no employment and with no formal education. ${ }^{[6]}$

Similarly, $76 \%$ of the respondents said that lower level of education was contributing factor of teenage pregnancy, which was similar to the finding of the study by Philemon which found that some of the respondents were already dropouts from school, while others were deprived of the chance with secondary education. ${ }^{[7]}$

Less strictness of guardians in trying to monitor activities and lack of knowledge about disadvantage of teenage pregnancy were contributing factors of teenage pregnancy in 58\% respondents, which was similar to study conducted by Mithiba et al. which shows that lack of strictness in family lack of knowledge on disadvantage of teenage pregnancy as contributing to teenage pregnancy. ${ }^{[8]}$

\section{Conclusion}

This study showed that adolescence pregnancies are still a major concern in Nepal especially among those who are living in rural areas. The main factors of teenage pregnancy were limited education and job 
opportunities, lack of awareness about teenage pregnancy, lack of knowledge about disadvantage of teenage pregnancy, unavailability of formal education about teenage pregnancy, cultural acceptance for early marriage and less strictness in guardians in trying to monitor activities.

\section{References}

[1] World health organization. Country Health System Profile Nepal: 2001. Retrieved from http://www.searo.who.int/en/Section313/Section1523_6870.htm

[2] Chedraui P, Hidalgo L, Chavez M, Glenda SM. Determinant factors related to pregnancy among adolescents aged 15 or less. Journal of Perinatal Medicine. 2004; April; 201-205.

[3] World Health Report. World Health Organization, Geneva. $2005 . \quad$ Retrieved from: http://www.who.int/whr/2005/media_centre/facts_en.pdf

[4] Nepal Department of Health Services.2010. Retrieved fromhttp://dohs.gov.np/sites/default/files/1/files/Annual_Report_2066_67.pdf

[5] Acharya DR, Bhattarai R, Poobalan A, Van Teijlingen, ER and Chapman G. Factors associated with teenage pregnancy in South Asia. Health science Journal 2010; 4(1).

[6] Muchuruza P. Socio economic and cultural factors associated with pregnancy among adolescent girls in magu district. 2002. Retrievedfromhttp://www.mcdgc.go.tz/catalogue/index.php/view/socio_economic_and_cultural_factors_associated_with_pregnanc y_among adolesc

[7] Philemon M. Factors contributing to high adolescent pregnancy rate in kinondoni municipality, dar-es- saloam, Tanzania. 2007. Retrieved from http://uir.unisa.ac.za/bitstream/handle/10500/1814/dissertation.pdf.txt?sequence=2

[8] Mithiba TM, Maputle MS, tebogo M, Maria S, Liaws, Hasan, Wade V, Fernando. Risk factors for teenage pregnancies in Sri Lanka. 2013; Retrievedfromhttp://www.curationis.org.za/index.php/curationis/article/view/19/63 